\title{
Research and Development of Micro Porous Concrete and Polystyrene Foam Plastics in Composite Wall Material
}

\author{
Wangzhi CAO \\ School of Civil Engineering, Northwest University for \\ Nationalities, Lanzhou 730124, China \\ Key Laboratory of New Building Materials and Building \\ Energy Efficiency in Gansu Province, Lanzhou 730124, \\ Gansu, China \\ Lanzhou Minda Civil Engineering Science and \\ Technology Co., Ltd. Lanzhou 730050, China \\ E-mail: 13321202029@126.com

\section{Hongzhen WANG} \\ School of Civil Engineering, Northwest University for \\ Nationalities, Lanzhou 730124, China \\ Key Laboratory of New Building Materials and Building \\ Energy Efficiency in Gansu Province, Lanzhou 730124, \\ Gansu, China \\ Lanzhou Minda Civil Engineering Science and \\ Technology Co., Ltd. Lanzhou 730050, China
}

\begin{abstract}
This paper introduces the rapid hardening sulphoaluminate cement as cementitious materials, polypropylene short cut fiber as reinforcing material. Through the development of physical foaming cellular concrete and polystyrene foam plastic board, craft processes and product performance of non-load-bearing wall by sandwich composite, which provides a technical idea for the development of new wall materials in northern China.
\end{abstract}

Keywords-cellular concrete; polystyrene foam board; wall material products; building energy conservation; durable fire protection

\section{INTRODUCTION}

Wall material is the key to determine whether the structure of the building for lifetime energy saving. External thermal insulation of building has exterior insulation, internal insulation and sandwich insulation in three ways. After years of market choice, polystyrene foamed plastic board thin plastering exterior insulation system accounted for more than $95 \%$ in China external wall thermal insulation projects. However, there are two major defects in the system: one is the durability problem, two is the fire safety problem. The inevitable trend of large area cracking of the national external wall thermal insulation layer as well as large and small fires in building exterior wall, which did not slow down the application pace of polystyrene board exterior wall insulation system, one of the main reasons is lack of real sense of all fire protection, durability, self insulation, construction convenient, affordable wall materials.

The Ministry of Construction of China Technical

\author{
Fangjie SHAO \\ Key Laboratory of Disaster Prevention and Mitigation \\ in Civil Engineering of Gansu Province, Lanzhou \\ University of Technology, Lanzhou 730050, China
}

\section{Yongheng YANG}

School of Civil Engineering, Northwest University for Nationalities, Lanzhou 730124, China

Key Laboratory of New Building Materials and Building Energy Efficiency in Gansu Province, Lanzhou 730124, Gansu, China

Lanzhou Minda Civil Engineering Science and Technology Co., Ltd. Lanzhou 730050, China

specification for exterior thermal insulation of external walls(JGJ144-2004)shall not be less than 25 years for the use of external insulation for external walls. Code for design of civil buildings provides the use of important buildings and high-rise buildings life span of 100 years, general building 50-100 years. Obviously, the service life of external wall insulation project is less than half of the main building.

To consider from the fire prevention requirements, inorganic materials as wall insulation materials are the most ideal. However, he thermal conductivity of inorganic materials can not meet the requirements of building energy efficiency in cold and chill regions. It is difficult in aspects of process control, quality assurance and raw material source. Organic foaming materials are compounded with inorganic materials, they can completely overcome the problem of poor fire resistance and durability and are the most realistic choice of building external wall thermal insulation materials.

Based on the above background, we developed acomposite sandwich product that micro porous concretes encased polystyrene foaming board, and promoted rapidly in the country.

\section{Product STRUCTURE}

Through inorganic non combustible and refractory micro porous concrete thermal insulation material wrapped organic foaming thermal insulation core material, blocking the contact of organic material with air, making the final products achieve fire prevention at the same time of heat preservation and heat insulation. 
Building block specifications: long 600(1200)mm, high $300 \mathrm{~mm}$, thick $250(200,150,120) \mathrm{mm}$; volumetric weight: $400-600 \mathrm{Kg} / \mathrm{m} 3$.Base material micro porous lightweight concrete volumetric weight:800-1200 kg/m3, compressive strength $2.0-4.5 \mathrm{Mpa}$.

Outer wall thickness of sandwich block is not less than $25 \mathrm{~mm}$, rib thickness is not less than $15 \mathrm{~mm}$.

\section{DEVELOPMENT OF FIBER REINFORCED LiGHTWEIGHT Aggregate Micropore Lightweight Concrete MATERIALS}

This kind of concrete we developed is based on rapid hardening sulphoaluminate cements and a few common portland cements as the main cementitious materials, polypropylene and inorganic modified short fiber as reinforcing material, the ceramsite, slag, slag brick, expanded perlite, etc. as lightweight aggregate. A lightweight concrete is made by the method of introducing a small foam in the preparation process, lightweight concrete with fiber reinforced light aggregate.

\section{A. Raw Materials for Micro Porous Concrete}

1) Cementitious materials: 42.5 level rapid-hardening sulphoaluminate cement, can conform to sulphoaluminate cement(GB 20472-2006)standard requirements. Ordinary portland cement as modified materials of cementitious materials, can meet the requirements of Common Portland Cement (GB175-2007)standard requirements.

2) Lightweight aggregate: the choice of ceramsite, blast furnace slag, slag, waste brick slag and expanded perlite use cooperatively. Natural aggregate gradation, due to the limitation of the wall thickness of the product, maximum particle size should be less than $10 \mathrm{~mm}$.Bulk density of ceramsite and slag $600-800 \mathrm{~kg} / \mathrm{m}^{3}$; bulk density of blast furnace slag $1100-1200 \mathrm{~kg} / \mathrm{m}^{3}$; bulk density of waste brick slag $800-1000 \mathrm{~kg} / \mathrm{m}^{3}$; bulk density of expanded perlite 100 $200 \mathrm{~kg} / \mathrm{m}^{3}$.

3) Reinforced fiber: choose $8 \mathrm{~mm}$ long inorganic mineral fiber and polypropylene chopped fiber composite, after the treatment of highly efficient dispersing agent developed by ourselves can be evenly dispersed in lightweight aggregate micro porous concrete.

\section{B. Micro Porous Concrete Mix Proportion}

Taking the density 500 grade block as an example, control slurry density less than $1200 \mathrm{~kg} / \mathrm{m} 3$.Per cubic meter of micro porous concrete materials dosage, rapid hardening cement $300 \mathrm{~kg}$, lightweight aggregate $640 \mathrm{~kg}$, micro bubble agent $20 \mathrm{~kg}$, short fiber $1.0 \mathrm{~kg}$, rubber powder (HF2000 water solubility) $1.5 \mathrm{~kg}$, water cement ratio 0.9 .

\section{Fabrication Process and Properties of Micro Porous Concrete}

Micro porous lightweight concrete using our invention "compressed air foam generator" technology, using air compressor, under the pressure of more than 0.5 $\mathrm{MPa}$, the $\mathrm{pH}$ value of about $8 \mathrm{HF}-1$ type sulfonate series micro bubble agent through the "compressed air foam generator" convert into tiny bubble diameter of less than $1 \mathrm{~mm}$, and then mixes with self-leveling concrete slurry which water cement ratio greater than 0.6 ,make porous lightweight concrete slurry with a volume quality of $800 \sim 1100 \mathrm{~kg} / \mathrm{m} 3$, implement a uniform and stable formation of micropores. Adding lightweight aggregates to the above micropore lightweight concrete can produce volumetric weight $900 \sim 1200 \mathrm{~kg} / \mathrm{m} 3$ light aggregate micro porous lightweight concrete.

The basic properties of micro porous concrete are shown in Tab.1.

TABLE I. BASIC PROPERTIES OF MicRo POROUS CONCRETE

\begin{tabular}{lccc}
\hline $\begin{array}{l}\text { VolumetricW } \\
\text { eight }\left(\mathbf{K g} / \mathbf{m}^{\mathbf{3}}\right)\end{array}$ & $\begin{array}{c}\text { Weight Water } \\
\text { Absorption }(\%)\end{array}$ & $\begin{array}{c}\text { Thermal } \\
\text { Conductivity } \\
(\mathbf{W} /(\mathbf{m} \cdot \mathbf{k})\end{array}$ & $\begin{array}{c}\text { Compressive } \\
\text { Strength(MPa) }\end{array}$ \\
\hline $800 \sim 1200$ & 28.06 & $0.14-0.22$ & $2.0-4.5$ \\
\hline
\end{tabular}

As shown in fig. 1, the structure of the hole is enlarges 40 times. It can be seen that most of its hole' diameters are $0.3 \mathrm{~mm}$ or less, severals around $0.5 \mathrm{~mm}$. There is a $0.1-0.2 \mathrm{~mm}$ thickness of the hole wall between holes. Holes are independent of each other and not through.

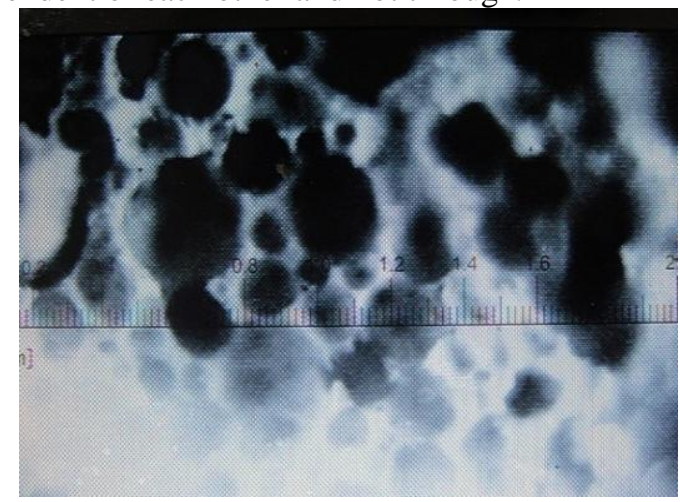

Figure 1. The photo that micro porous concrete section magnifies 40 times

\section{PRODUCTION PROCESS OF COMPOSITE SANDWICH PRODUCTS}

The composite of the above micropore concrete and the thermal insulation core material forms sandwich composite block, photo is shown in fig. 2 .

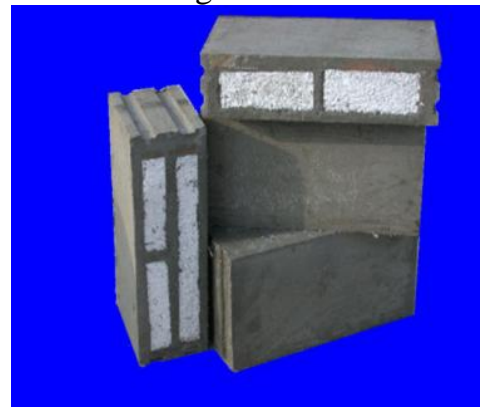

Figure 2. Sandwich composite block product photo 


\section{A. Raw Materials for Sandwich Blocks}

1) Micro porous concrete: meet the requirements of table 1.

2) Thermal insulation core material: Organic core material is polystyrene foaming board, volumetric weight less than $15 \mathrm{~kg} / \mathrm{m}^{3}$, thermal conductivity is not more than $0.042 \mathrm{~W} / \mathrm{m} \cdot \mathrm{K}$. Fire resistance meet national standards (GB 8624-2006) A2, B or C level requirements.

3) Foaming agent and release agent: use homemade third generation HF-3 sulfonate series foaming agent. Foaming and foam stability good, apply to air compression foam process. Release agent chooses homemade HF-2 type emulsified oil soap lye, with non-toxic, tasteless, high isolation and non polluting properties of product surface, etc. can be used in spraying technology.

\section{B. Material Composition}

Micro porous concrete and thermal insulation core material each $0.5 \mathrm{~m}^{3}$, release agent $2 \mathrm{~kg}$ per cubic meter.

\section{Production Process}

\section{1) Process key link}

Batching system, foam production and supply foam system, stirring casting and slurry scraping system, molding system, product automatic clamping and stripping crane system, automatic palletizing system, chain plate conveyor system, model car ferry system, maintenance system, etc. For the above system we developed special equipments and DCS, PLC automatic control system. This technology has strong adaptability, the core materials can be organic foaming materials, also can be full of inorganic glass cotton, rock wool, hydrophobic glass beads or perlite insulation board.

2) Main technical parameters

Volume quality of micro porous lightweight concrete slurry $900-1100 \mathrm{~kg} / \mathrm{m}^{3}$.

$\begin{array}{cc}\text { casting cycle } & 6 \mathrm{~min} \\ \text { casting temperature } & 40-50^{\circ} \mathrm{C} \\ \text { rest time } & 30 \mathrm{~min} \\ \text { dry and thermal curing time } & 4 \mathrm{~h} \\ \text { dry and thermal curing temperature } & 40-50^{\circ} \mathrm{C} \\ \text { pressure of air pressure and foaming } & \geq 0.5 \mathrm{MPa}\end{array}$

In the casting cycle, the $2 \mathrm{~min}$ is put into the dry materials, making foam and stirring $2 \mathrm{~min}$, pouring into mold 2 min.

\section{Main Technical Indexes of Products}

Product combustion performance: inorganic base material and organic core material composite (sandwich) products fireproof performance meet GB 8624-1997 Classification on burning behaviour for building materials incombustible materials A grade composite (sandwich) materials requirements.

Drying shrinkage, freezing resistance, thermal conductivity, masonry thermal resistance, sound insulation, fire endurance and other physical performance indicators are shown in Tab. 2.

TABLE II. PHysical Property INDEXES OF HEAT INSUlation AND ENERGY SAVING COMPOSITE BLOCK

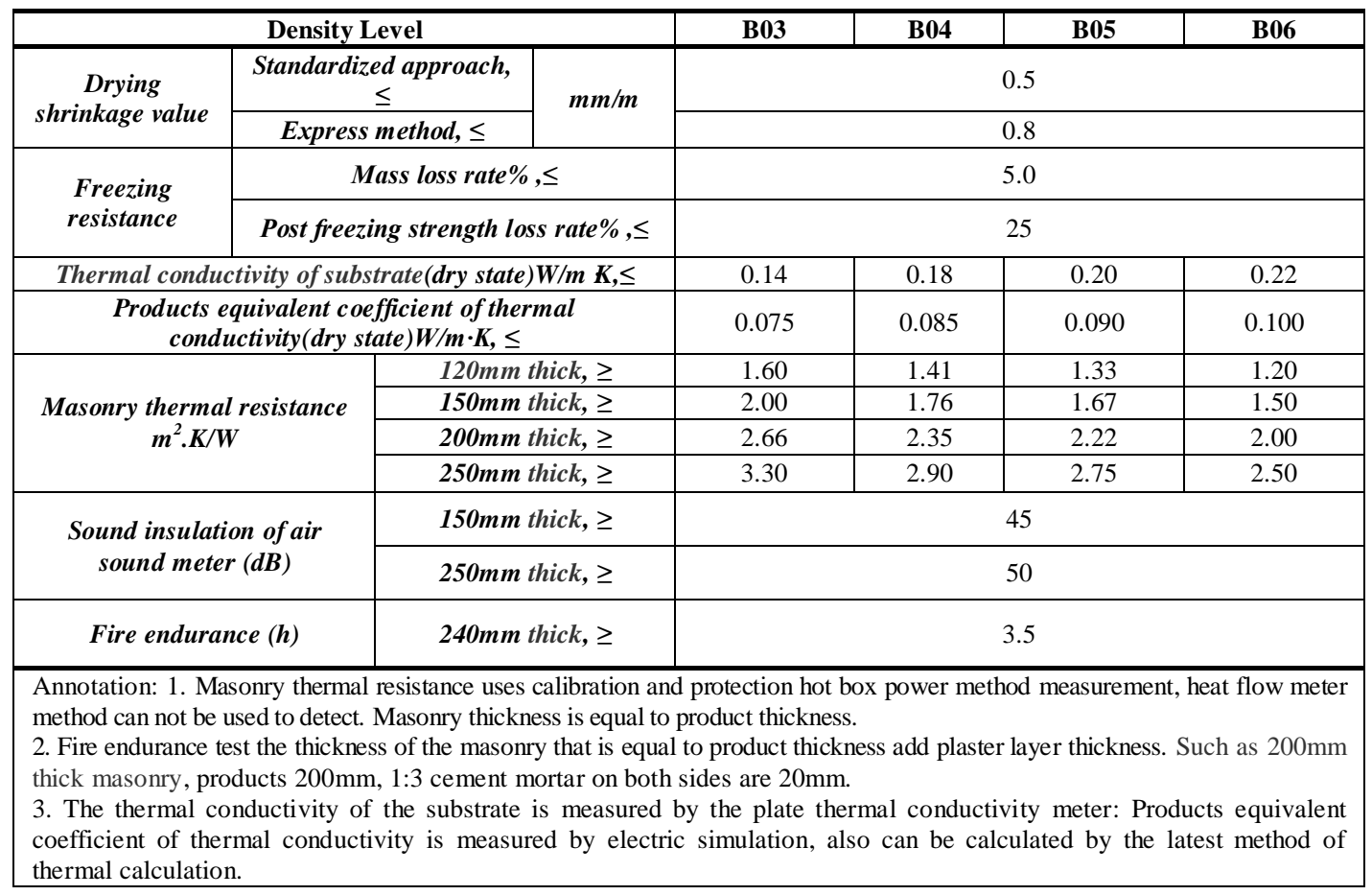


According to The Nation Prevents Fire Building Material Quantity Direct Examination Center in accordance with Fire-resistance tests-Elements of building construction GB/T9978.1-2008 and GB/T9978.8-2008 detection, the fire endurance of the product masonry wall can be up to 3.5 hours. Detection with metope $3 \times 3 \mathrm{~m}$, by the $200 \mathrm{~mm}$ thick block staggered joint masonry, the ash seam is less than $10 \mathrm{~mm}$, the both walls use ordinary cement mortar plaster $20 \mathrm{~mm}$ after they turn into the wall. Wall surface by fire in the furnace temperature $1136.40^{\circ} \mathrm{C}$ calcinates after $3.5 \mathrm{~h}$, on the other side of the wall, the surface temperature rise average of 10 monitoring points is $16.26^{\circ} \mathrm{C}$, only the standard set limit of the average temperature rise $140^{\circ} \mathrm{C}$ of $12 \%$. The highest point heating up value $93.32^{\circ} \mathrm{C}$, only half of the standard requirements $180^{\circ} \mathrm{C}$, two surfaces of the wall are not destroyed, polystyrene core materials near the outer surface are intact. The polystyrene core material softens near the fire surface, but they are not on fire. We can see from fig. 3 the wall state near fire side, after the experiment is finished, the plaster layer expands and drops, block is intact. Fig. 4 is the experiment that brazing torch grills for 10 minutes in high temperature without destruction of the product.

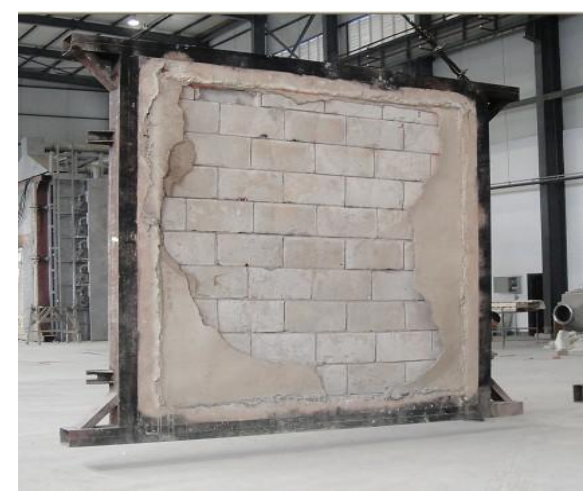

Figure 3. The wall is out of the furnace by the fire side when barbecued after $3.5 \mathrm{~h}$

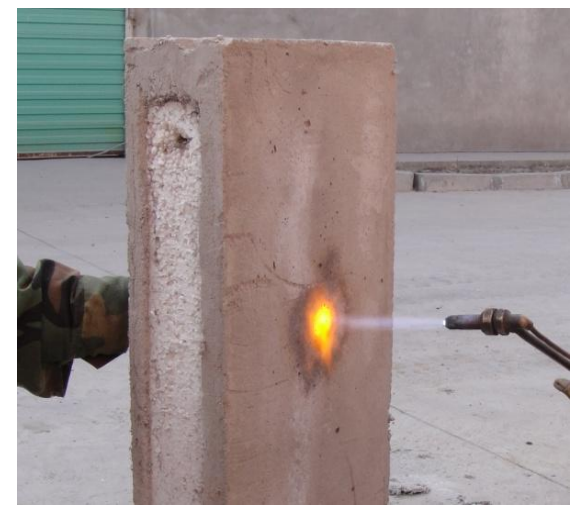

Figure 4. Experiment that brazing torch grills for 10 minutes in high temperature without destruction of the product

\section{Social Benefits ANd ApPlications}

As the building external wall thermal insulation use, per cubic metre block compared with traditional aerated concrete, can use industrial waste slag $250 \mathrm{~kg}$, saving heating energy consumption $119 \mathrm{~kg}$ standard coal, saving production energy consumption $33 \mathrm{~kg}$ standard coal. Compared with the traditional materials energy-saving wall of composite masonry, the cost of the wall is reduced about 30\%, the wall thickness thinning about $33 \%$ and wall weight reduce more than $40 \%$. According to the calculation of the annual new wall materials'total 674 million $\mathrm{m}^{3}$, if the product market share can reach $15 \%$, they can save 107.8 billion yuan, energy-saving 15.37 million tons standard coal, using industrial waste residue 25.28 million tons, reducing carbon dioxide emissions 38.3 million tons.

Products can be used for the frame structure infilled wall, shear wall structure and brick concrete structure loadbearing wall exterior insulation. Project in Northwest China and Shandong province promotes and applys for five years, engineering application more than 300 , total more than 550000 cubic meters, sales greater than 210 million yuan, the savings amount 590 million yuan.

\section{CONCLUSIONS}

- Through inorganic non combustible and refractory micro porous concrete thermal insulation material wrapped organic foaming thermal insulation core material, blocking the contact of organic material with air, making the final products achieve fire prevention at the same time of thermal insulation and heat insulation.

- The surface layer of the sandwich product is fully inorganic micro porous concrete, which can realize the same life with the main body of the building, which avoids the unavoidable maintenance and replacement of the traditional thermal insulation layer, and saves resources.

- The product are firmly bonded to plastering layer mortar, the wall is not easy to hollowing and cracking.

- Product raw material source is wide, the technology is easy to operate, the area is strongly adaptable.

- Compared with the traditional approach, the cost of the wall is reduced about $30 \%$, the wall weight is reduced more than $40 \%$.

\section{REFERENCES}

[1] Wang Hongzhen, Yang Junxiao.Experimental study on the flow pattern of lightweight aggregate micropore concrete[J]. Journal of Building Materials,2011(2):263-268.

[2] Xiao Liguang, Hou Qichao.Research progress and application of foamed concrete[J].Journal of Jilin Architectural and Civil Engineering, 2011(5):32-36.

[3] Wei Wenhui. Analysis and application of foamed concrete[J]. Concrete, 2013(02):36-38.

[4] Wanzhi Cao,The Comprehensive Study about Fireproof and Single Insulation Walls for Cold Regions[J]. Applied Mechanics and Materials Vols. 99-100 (2011) pp 1043-1051. 